\title{
Perception about Coughing Disease among University Students
}

\author{
Muhammad Imran Qadir ${ }^{1}$ and Arslan Hassan ${ }^{2 *}$ \\ 1,2Institute of Molecular Biology and Biotechnology, Bahauddin Zakariya University, Multan, Pakistan
}

*Corresponding author: Arslan Hassan, Institute of Molecular Biology and Biotechnology, Bahauddin Zakariya University, Multan, Pakistan

Received Date: June 20, 2019

Published Date: June 21, 2019

\begin{abstract}
The objective of the present study was the perception of coughing among university students Coughing makes noise when sudden exhale of air done and virus brings up changes in neuron physiology which leads to sneezing and parasympathetically responses excretions in bronchi lead to coughing. Some symptoms are fever, chest painfulness, breathing difficulty. There are two types of sources exogenous and endogenous which leads to coughing. From the survey of university students mostly people said coughing is viral disease and almost all people suffer from coughing. As it is more common but it is not a genetic disease and not transmitted by any contact and blood transfusion among people. It can be cured by medicines and some said that for this disease there is no need for any treatment.
\end{abstract}

Keywords: Coughing; Neural alleyways; Neuron physiology

\section{Introduction}

Coughing is sudden exhale of air from lungs with making noise. In nasals airlines virus brought changes in neuron physiology primes to sneezing and parasympathetically response excretions whereas in bronchia which lead to coughing. There are mainly three types of coughing acute cough, subacute cough, and chronic coughing. From these three types mostly, acute type is found in people and lasts for maximum three weeks. This is caused by the viral infection other types may cause by bacteria also. Coughing always show irritating signs for patient and makes him lazy and sleepy all day. Some symptoms are fever, chest painfulness, breathing difficulty. In some cases, acute can change into chronic coughing where coughing and abnormal air passage feelings longs outlive than primary virus infection [1]. This proposes that few viruses have the ability to make insistent flexibility in the neural alleyways arbitrating coughing. This is typically notice that virus persuaded coughing that can continue fit out there the time desired for clearing of the virus infections. By changing the nervous system, respirational viruses thrive in escape but mostly leaves beyond hosts with extreme coughing respirational disease. Coughing may have different timing. It may morning cough or smoker cough, day coughing, night coughing and all-day long coughing. There may different types of sources some are exogenous some are endogenous which leads to inflammation, constriction, or compression of airways which resulted to cough [2,3].

The objective of the present study was the perception of coughing among university students.

\section{Material and Methods}

\section{Method}

As it was survey so no scientific method was available. For the perception and awareness of coughing we met with the university students and consented them whether they know about Coughing or not. Most of them students knew that coughing was viral disease and they told that coughing was one of common diseases and not spread through any contact or blood transfusion and we wrote on our list[4,5].Total 112 students participated in this study. All the students were of Bahauddin Zakariya University Multan, Pakistan $[6,7]$.

\section{Result and Discussion}

(Figure 1-4) 


\section{IS COUGHING A}

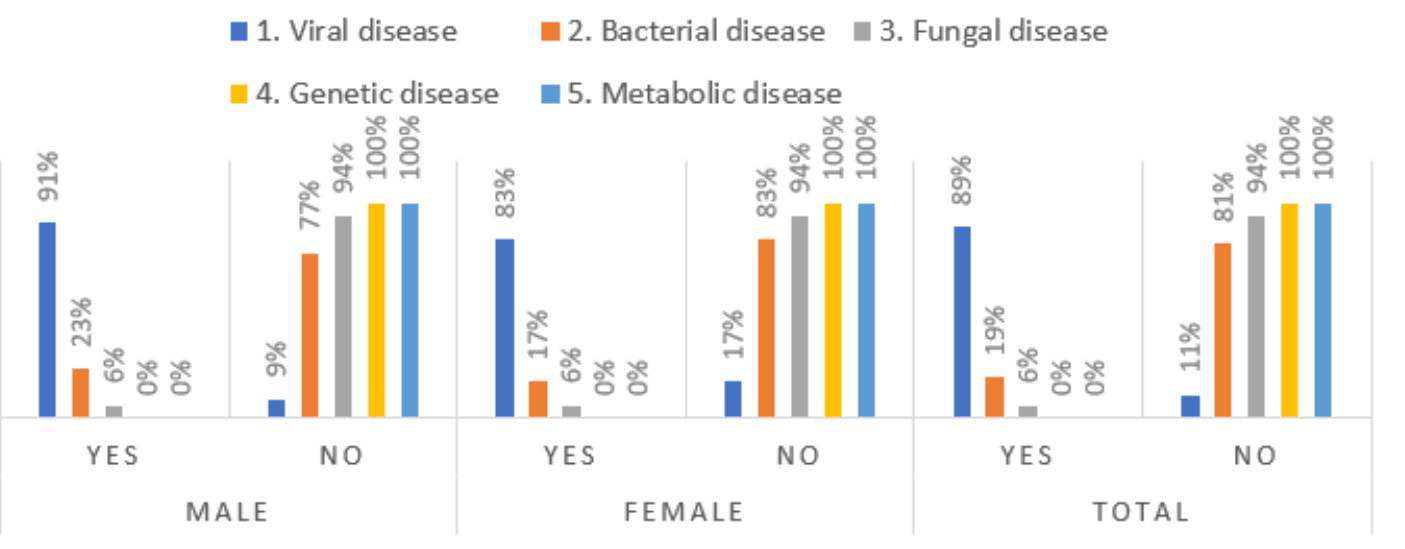

Figure 1: Questionnaire to evaluate the type of disease Coughing is from the Figure 1 we concluded that mostly people said coughing is a viral disease but some of that said it is also a bacterial disease. It means mostly people knows about coughing is a viral disease.
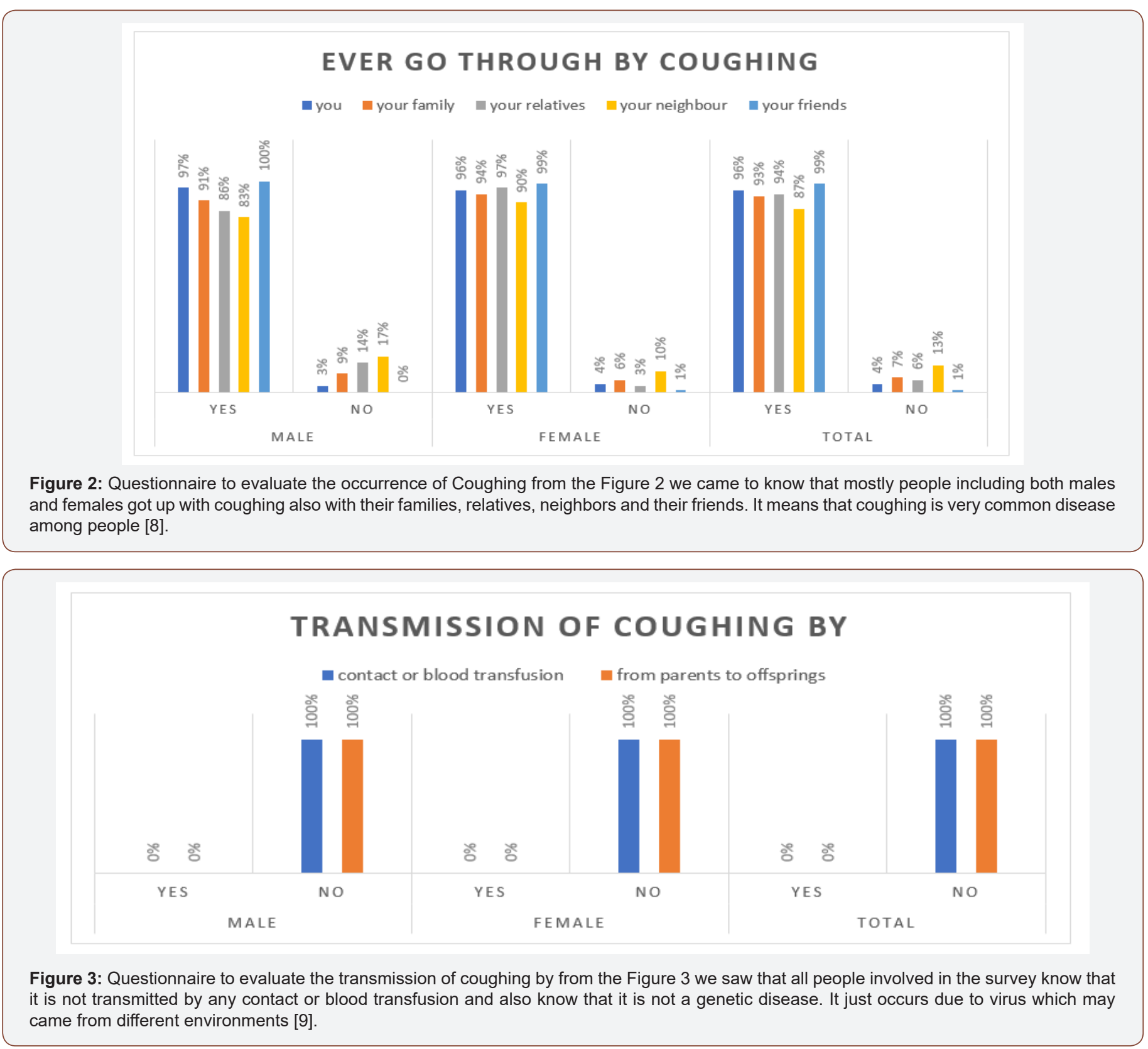


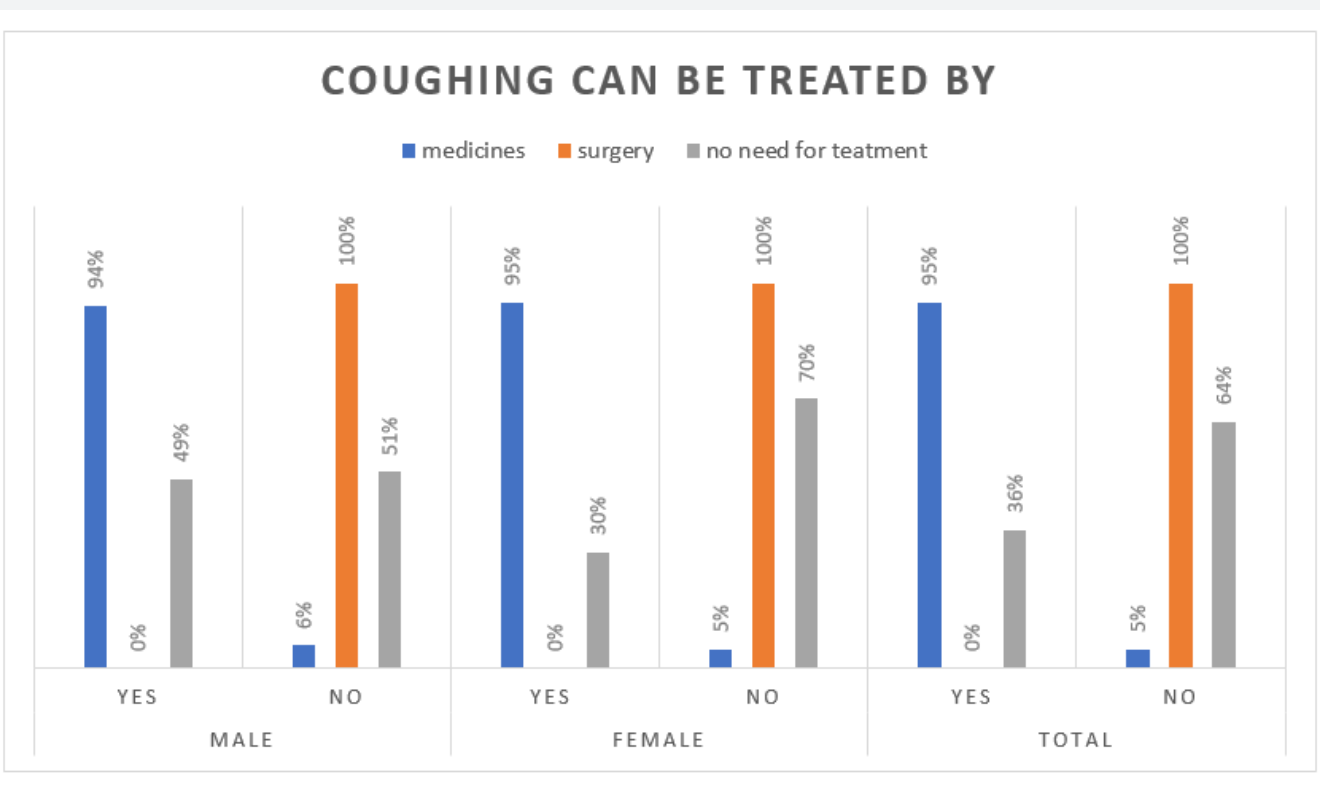

Figure 4: Questionnaire to evaluate the treatment of Coughing from the Figure 4 we noted that coughing is viral disease and almost all people in survey said that it can be cured by medicines. Surgery is not for treatment of coughing and half of male said that no need for any treatment and less than half females said no need for treatment. Totally more than half people said it must be treated by any medicines [10].

\section{Conclusion}

We concluded from the present study that mostly people thought that coughing is a viral disease and almost all people go through this disease and they also know that it can be cured by medicines.

\section{Acknowledgment}

None.

\section{Conflict of Interest}

No conflict of interest.

\section{References}

1. Boiselle PM, Lee KS, Lin S, Raptopoulos V (2006) Cine CT during coughing for assessment of tracheomalacia: preliminary experience with 64-MDCT. American Journal of Roentgenology 187(2): W175-177.

2. Lawson TV(1967) Assessment of the mechanical effeciency of coughing in healthy young adults. Clin Sci 33(1): 209-224.
3. Qadir MI, Javid A (2018) Awareness about Crohn's Disease in biotechnology students. Glo Adv Res J Med Medical Sci 7(3): 062-064.

4. Qadir MI, Saleem A (2018) Awareness about ischemic heart disease in university biotechnology students. Glo Adv Res J Med Medical Sci 7(3): 059-061.

5. Qadir MI, Ishfaq S (2018) Awareness about hypertension in biology students. Int J Mod Pharma Res 7(2): 08-10.

6. Qadir MI, Mehwish (2018) Awareness about psoriasis disease. Int J Mod Pharma Res 7(2): 17-18.

7. Qadir MI, Shahzad R (2018) Awareness about obesity in postgraduate students of biotechnology. Int J Mod Pharma Res 7(2): 14-16.

8. Qadir MI, Rizvi M (2018) Awareness about thalassemia in post graduate students. MOJ Lymphology \& Phlebology 2(1): 14-16.

9. Qadir MI, Ghalia BA (2018) Awareness survey about colorectal cancer in students of M. Phil Biotechnology at Bahauddin Zakariya University, Multan, Pakistan. Nov Appro in Can Study 1(3): NACS.000514.2018.

10. Qadir MI, Saba G (2018) Awareness about intestinal cancer in university student. Nov Appro in Can Study 1(3): NACS.000515.2018. 